\title{
Penerapan Model active Knowledge Sharing dalam Pembelajaran Matematika Siswa Kelas VII di SMPN 18 Palembang
}

\author{
LEARNING WITH SEARCh-SOLVE-CREATE-SHARE STRATEGY TO TRAIN \\ MATHEMATICS BASIC TEACHING SKILLS
}

\author{
Eka Fitri Puspa Sari \\ Universitas PGRI Palembang \\ Palembang, Sumatera Selatan, Indonesia \\ e_etha@rocketmail.com
}

\begin{abstract}
Abstrak
Penelitian ini bertujuan untuk mengetahui keaktifan dan hasil belajar siswa setelah diterapkannya model pembelajaran Active Knowledge Sharing. Subjek penelitian adalah siswa-siswi SMP N 18 Palembang kelas $\mathrm{VII}_{1}$ yang berjumlah 40 orang. Pengumpulan data menggunakan lembar observasi untuk mengetahui keaktifan siswa setelah diterapkannya model pembelajaran Active Knowledge Sharing. Berdasarkan analisis data observasi diperoleh nilai rata-rata 13,0 dikategorikan tinggi dalam rentang 4-16. Selanjutnya pengumpulan data menggunakan LKS, PR dan tes akhir dilakukan untuk mengetahui hasil belajar siswa setelah diterapkannya model pembelajaran Active Knowledge Sharing. Dari hasil belajar yang telah dianalisis diperoleh ratarata hasil belajar siswa 75,4 .
\end{abstract}

Kata Kunci: model pembelajaran Active Knowledge Sharing, keaktifan, hasil belajar.

\begin{abstract}
This study aims to determine the activity and student learning outcomes after the implementation of Active Knowledge Sharing learning model. The subjects were students of SMP N 18 Palembang VIII classes totaling 40 people. Collecting data using observation sheet to know the students' activity after the implementation of Active Knowledge Sharing learning model. Based on the analysis of observational data obtained by the average value of 13.0 categorized as high in the range of 4-16. Further data collection using the worksheets, homework and the final test is performed to determine student learning outcomes after the implementation of Active Knowledge Sharing learning model. From the results of the study have been analyzed gained an average of 75.4 students' learning outcomes.
\end{abstract}

Keyword: Active Knowledge Sharing learning model, activeness, learning outcomes.

\section{Pendahuluan}

Salah satu masalah dalam pembelajaran matematika yang sering dikeluhkan oleh para guru dan masyarakat adalah hasil belajar siswa. Secara teoritis, hasil belajar dipengaruhi oleh berbagai faktor, baik faktor dari dalam maupun faktor dari luar.
Menurut Benyamin Bloom [1] mengemukakan tiga faktor utama yang mempengaruhi hasil belajar siswa yaitu; (1) kemampuan kognitif; (2) motivasi berprestasi; (3) kualitas pembelajaran.

Berdasarkan hasil observasi yang peneliti lakukan didapatkan bahwa siswa 
lebih bosan dalam belajar matematika. Hal itu disebabkan karena pembelajaran dilakukan secara klasikal, akibatnya aktivitas siswa rendah dan siswa cenderung lebih pasif karena mengalami kesulitan belajar, sehingga peserta didik pun tidak dapat mencapai skor minimal yang ditetapkan. Maka dari itu pembelajaran yang baik adalah pembelajaran yang melibatkan siswa secara aktif.

Bertolak dari uraian di atas, maka diperlukan suatu model pembelajaran yang dapat membuat siswa-siswi secara aktif ikut serta selama pembelajaran berlangsung.

Ada banyak model pembelajaran yang dapat digunakan dalam pembelajaran di sekolah khususnya pembelajaran matematika. Mel Silberman [2] mengemukakan 101 bentuk model pembelajaran yang dapat digunakan dalam pembelajaran aktif. Salah satu model pembelajaran itu yaitu Active Knowledge Sharing. Oleh karena itu perlu dilakukan penelitian yang berjudul 'Penerapan model active knowledge sharing dalam pembelajaran matematika siswa kelas vii di smp n 18 palembang'.

Adapun yang menjadi masalah dalam penelitian ini adalah "Bagaimana keaktifan dan hasil belajar matematika siswa di kelas VII SMP N 18 Palembang setelah diterapkannya model pembelajaran Active Knowledge Sharing dalam pembelajaran matematika"

Penelitian ini betujuan untuk mengetahui gambaran keaktifan dan hasil belajar matematika siswa di kelas VII SMP N 18 Palembang setelah diterapkannya model pembelajaran Active Knowledge Sharing dalam pembelajaran matematika.

\section{A. Tujuan Pembelajaran Matematika}

Pelajaran matematika adalah salah satu pelajaran yang dipelajari siswa mulai dari sekolah dasar sampai perguruan tinggi. Menurut Soedjadi [3] matematika memiliki karakteristik; (1) memiliki obyek kajian abstrak; (2) bertumpu pada kesepakatan; (3) berpola pikir deduktif; (4) memiliki simbol yang kosong dari arti; (5) memperhatikan semesta pembicaraan; (6) konsisten dalam sistemnya.

Dalam kegiatan belajar mengajar, dikenal adanya tujuan pengajaran atau tujuan instruksional dan tujuan kurikuler. Tujuan pengajaran adalah tujuan dari suatu proses interaksi antara guru dan siswa dalam kegiatan belajar mengajar dalam rangka mencapai tujuan pendidikan.

Adapun tujuan kurikuler dari pengajaran matematika adalah:

1. Melatih cara berfikir dan bernalar dalam menarik kesimpulan.

2. Mengembangkan aktivitas kreatif yang melibatkan imajinasi, intuisi dan penemuan dengan mengembangkan pemikiran orisinil dan rasa ingin tahu.

3. Mengembangkan kemampuan memecahkan masalah.

4. Mengembangkan kemampuan menyampaikan informasi atau mengkomunikasikan gagasan antara lain melalui pembicaraan lisan ataupun catatan.

Secara garis besar tujuan pembelajaran maematika adalah terbentuknya kemampuan bernalar pada diri siswa yang 
tercermin melalui kemampuaan berpikir kritis, logis, sistematis dan memiliki sifat obyektif, jujur, disiplin dalam memecahkan suatu permasalahan dalam bidang matematika.

\section{B. Model Pembelajaran Active Knowledge Sharing}

Model pembelajaran ini berbeda dengan model pembelajaran metode diskusi, karena pada model pembelajaran Active Knowledge Sharing ini guru terlebih dahulu menyiapkan daftar pertanyaan berupa LKS yang kemudian dibagikan kepada siswa. Adapun langkahlangkah pembelajaran Active Knowledge Sharing menurut Mel Silberman [2] yaitu:

1. Guru menyiapkan daftar pertanyaan yang berkaitan dengan materi pembelajaran yang diajarkan.

2. Guru membentuk kelompok yang beranggotakan 4orang.

3. Guru membagikan pertanyaan yang ditujukan kepada masing-masing kelompok.

4. Guru meminta siswa untuk menjawab pertanyaan.

5. Guru meminta salah satu siswa dari masing-masing kelompok untuk menyebar di dalam ruangan, mencari siswa dari kelompok lain yang dapat menjawab pertanyaan yang mereka tidak bisa menjawabnya. Pada kegiatan ini guru mendorong siswa untuk membagi pengetahuan mereka secara aktif.

6. Guru meminta siswa untuk kembali ke tempat kelompoknya semula.

7. Guru bersama-sama siswa membahas jawaban yang telah mereka dapatkan.
8. Guru bersama siswa menyimpulkan materi.

9. Guru memberikan evaluasi.

\section{Aktivitas Siswa}

Hal yang harus dilakukan guru pada awal pembeajaran adalah membangun minat, rasa ingin tahu dan merangsang siswa untuk berfikir. Bila minat siswa, rasa ingin tahu siswa telah bangkit hal ini berarti siswa telah siap secara mental untuk terlibat secara aktif dalam pembelajaran matematika.

Menurut Uzer Usman [4], aktivitas belajar meliputi; (1) aktivitas visual seperti membaca, menulis, melakukan eksperimen, dan demonstrasi; (2) aktivitas lisan seperti bercerita, membaca sajak, tanya jawab, diskusi dan menyanyi; (3) aktivitas mendengarkan seperti mendengarkan penjelasan guru, ceramah dan pengarahan; (4) aktivitas gerak seperti senam, atletik, menari dan melukis.

\section{Hasil Belajar}

Secara khusus dalam pembelajaran di kelas, penilaian dilakukan untuk mengetahui kemajuan dan hasil belajar siswa, memberikan umpan balik dan penentuan kenaikan kelas. Adapun penilaian yang dapat dilakukan oleh guru dapat berupa tugas kelompok, portofolio, tugas individu misalnya mengerjakan lembar kerja siswa, mengerjakan pekerjaan rumah dan mengerjakan soal ulangan.

Dalam petunjuk pelaksanaan proses belajar mengajar dikemukakan bahwa seorang siswa disebut bila ia mencapai skor $60 \%$ atau nilai 60. Suatu kelas 
dinyatakan tuntas belajar di kelas terdapat $85 \%$ yang telah mencapai daya serap lebih dari $60 \%$.

\section{Metode}

Penelitian ini termasuk dalam penelitian deskriptif yang bertujuan untuk menggambarkan penerapan model pembelajaran Active Knowledge Sharing dalam pembelajaran matematika siswa kelas VII di SMP N 18 Palembang. Berdasarkan rumusan masalah, maka variabel penelitian ini adalah keaktifan siswa dan hasil belajar siswa.

Subjek dalam penelitian ini adalah siswa kelas VII $_{1}$ SMP N 18 Palembang yang berjumlah 40 orang. Teknik pengumpulan data dalam penelitian ini menggunakan observasi dan tes.

\section{A. Analisis Data Observasi}

Data yang didapatkan dari lembar observasi diberi skor 1-4 sesuai dengan penilaian pengamat selama proses pembelajaran berlangsung. Adapun kriteria penskoran dalam data observasi yaitu:

Tabel 1. Kriteria Penskoran

\begin{tabular}{|cc|}
\hline Skor & Rubrik \\
\hline 1 & Ketiga deskriptor tidak ada yang muncul \\
\hline 2 & Jika satu deskriptor yang muncul \\
\hline 3 & Jika dua deskriptor yang muncul \\
\hline 4 & Jika tiga deskriptor yang muncul \\
\hline
\end{tabular}

Kemudian hasil yang didapat dihitung dengan rumus:

Nilai akhir $=\frac{\text { Jumlah skor yang diperoleh }}{\text { Jumlah skor maksimum }} \times 100$
Dari nilai akhir tersebut akan didapatkan penilaian aktifitas belajar siswa.

Tabel 2.

Penilaian aktivitas belajar siswa [5]

\begin{tabular}{|cc|}
\hline Skor & Kategori \\
\hline $13.6-16$ & Sangat baik \\
\hline $11.2-13.5$ & Baik \\
\hline $8.8-11.1$ & Cukup \\
\hline $6.4-8.7$ & Kurang \\
\hline $4.0-6.3$ & Sangat Kurang \\
\hline
\end{tabular}

\section{B. Analisis Data Tes}

Data yang didapat dari hasil LKS, PR dan tes siswa dianalisis gunanya untuk sejauh mana tingkat keberhasilan hasil belajar siswa-siswi setelah diterapkannya model pembelajaran Active Knowledge Sharing.

Langkah-langkah dalam menganalisis data tes hasil belajar siswa yaitu:

1. Memeriksa hail jawaban tes dan tugas.

2. Menjumlahkan skor semua jawaban dari tiap soal.

3. Skor akhir yang diperoleh siswa dikonversikan dalam bentuk nilai dengan rentang 0-100 dengan rumus:

Nilai akhir $=\frac{\text { Jumlah skor yang diperoleh }}{\text { Jumlah skor maksimum }} \times 100$

4. Rata-rata skor akhir yang diperoleh siswa yaitu merupakan hasil dari LKS, PR dan tes dengan menggunakan rumus:

$$
\text { Hasil belajar }=\frac{(25 P R+35 L K S+40 T e s)}{100}
$$

Penilaian hasil belajar dikategorikan menjadi dua yaitu:

1. Tuntas, jika hasil belajar dari peserta didik mencapai 59\% atau nilai 59. 
2. Tidak tuntas, jika hasil belajar peserta didik kurang dari 59\% atau nilai kurang dari 59.

\section{Hasil dan Pembahasan}

\section{A. Deskripsi Data Observasi}

Observasi dilakukan selama empat hari. Observer yang dibutuhkan sebanyak tiga orang. Penilaian observasi berdasarkan empat indikator dan masing-masing indikator mempunyai tiga deskriptor. Dari hasil observasi didapat hasil kategori aktivitas siswa sebagai berikut:

Tabel 3.

Kategori tingkat aktivitas siswa per pertemuan

\begin{tabular}{|ccc|}
\hline Pertemuan & $\begin{array}{c}\text { Jumlah nilai } \\
\text { yang diperoleh }\end{array}$ & Kategori \\
\hline 1 & 11.9 & Tinggi \\
\hline 2 & 12.1 & Tinggi \\
\hline 3 & 14.1 & Sangat tinggi \\
\hline 4 & 14.3 & Sangat tinggi \\
\hline Jumlah & 53.3 & \\
\hline Rata-rata & 13.3 & Tinggi \\
\hline
\end{tabular}

Berdasarkan tabel 3 di atas didapatkan bahwa pada pertemuan pertama dan kedua aktivitas siswa tinggi, ini dapat dilihat masing-masing nilai untuk pertemuan pertama dan kedua yaitu 11,9 dan 12,1 sedangkan pada pertemuan ketiga dan keempat aktivitas siswa dikategorikan sangat tinggi, ini dapat dilihat masingmasing nilai untuk pertemuan ketiga dan keempat yaitu 14,1 dan 14,3. Rata-rata aktivitas siswa selama pembelajaran berlangsung dikategorikan tinggi dengan nilai 13,3 .

\section{B. Deskripsi Data Hasil Belajar}

Data hasil belajar diperoleh dari penelitian yang dilakukan sebanyak 5 kali pertemuan yang terdiri dari empat hari pertemuan untuk penerapan model Active
Knowledge Sharing dan satu hari pertemuan untuk tes. Pada hari pertama sampai hari keempat siswa mengerjakan empat LKS dan PR kemudian hari kelima dilakukan tes.

\section{Analisis Data Observasi}

Hasil dari pengamatan yang dilakukan tiga observer kemudian dihitung berdasarkan muncul tidaknya deskriptor pada tiap-tiap indikator. Setelah dihitung kemudian ditetapkan kategori aktivitas siswa per individu.

Tabel 4.

Kategori Aktivitas Siswa Per Individu

\begin{tabular}{|cccc|}
\hline $\begin{array}{c}\text { Skor } \\
\text { Rata-rata }\end{array}$ & $\mathbf{F}$ & $\boldsymbol{\%}$ & Kategori \\
\hline $13.6-16$ & 7 & 17,25 & Sangat Tinggi \\
\hline $11.2-13.5$ & 29 & 72,5 & Tinggi \\
\hline $8.8-11.1$ & 4 & 10 & Cukup Tinggi \\
\hline $6.4-8.7$ & 0 & & Kurang \\
\hline $4.0-6.3$ & 0 & & Sangat Kurang \\
\hline Jumlah & 40 & 100 & \\
\hline Rata-rata & & 13,0 & Tinggi \\
\hline
\end{tabular}

Dari tabel 4 di atas dapat dilihat bahw ratarata aktivitas siswa per individu dikategorikan tinggi dengan nilai 13,0 itu artinya aktivitas siswa selama pembelajaran berlangsung dengan menggunakan model Active Knowledge Sharing tinggi.

\section{Analisis Data Hasil Belajar}

Data hasil belajar siswa diperoleh dari LKS yang diberikan sebanyak empat kali pertemuan, kemudian PR diberikan sebanyak empat kali juga dan har terakhir baru diberikan tes.

Tabel 5.

Kategori Hasil Belajar Siswa

\begin{tabular}{|cccc|}
\hline \multirow{2}{*}{ Nilai } & \multicolumn{2}{c}{ Hasil Belajar } & Kategori \\
\cline { 2 - 3 } & $\mathrm{F}$ & $\%$ & \\
\hline $59-100$ & 32 & 80 & Tuntas \\
\hline
\end{tabular}




\begin{tabular}{|cccc|}
\hline $0-58$ & 8 & 20 & Tidak Tuntas \\
\hline Jumlah & 40 & 100 & \\
\hline Rata-rata & & 75,4 & Tuntas
\end{tabular}

Dari tabel 5 di atas dapat dilihat bahwa rata-rata hasil beajar siswa yaitu 75,4 dikategorikan tuntas, artinya hasil belajar siswa tuntas.

\section{E. Pembahasan}

Berdasarkan hasil data observasi aktivitas siswa setelah diterapkannya model pembelajaran Active Knowledge Sharing didapatkan aktivitas siswa sangat tinggi terjadi pada pertemuan ketiga dan keempat, hal ini diakibatkan karena semua siswa telah bisa beradaptasi dengan model pembelajaran yang baru mereka terima, jadi siswa-siswi sangat antusias selama proses pembelajaran berlangsung.

Hal yang sulit ditemui pada pelaksanaan hari pertama penelitian yaitu siswa-siswi dalam menyelesaikan LKS kerjanya sendiri-sendiri, tidak mau berbagi pengetahuan dengan teman sebayanya. Walaupun hari pertama mengalami kesulitan tetapi hari-hari berikutnya siswasiswi mulai beradaptasi. Bisa dilihat pada tabel 4 yang merupakan aktivitas siswa per individu rata-rata nilainya 13,0 dikategorikan tinggi. Ini artinya model pembelajaran Active Knowledge Sharing dapat membuat siswa menjadi lebih aktif.

Pada saat penelitian berlangsung anakanak dikelompokkan menjadi sepuluh kelompok dengan masing-masing kelompok beranggotakan empat orang. Setiap kelompok diberikan LKS selama empat hari, gunanya yaitu sebagai sumber beajar yang menunjang dalam penelitian ini. Selain LKS, siswa juga diberikan PR gunanya yaitu sebagai latihan di rumah untuk mengulangi pelajaran yang telah diberikan peneliti.

Pada akhir penelitian, siswa diberikan tes akhir yang gunanya untuk melihat hasil belajar siswa setelah diterapkannya model pembelajaran Active Knowledge Sharing. Nilai tinggi yang didapat siswa adalah 100 dan terendah 40. Ada beberapa faktor yang mempengaruhi siswa mendapat nilai kurang maksimal salah satunya kurangnya pemahaman siswa dalam menjawab soalsoal tes dan kurangnya ketelitian siswa.

Soal: Sebuah keluarga terdiri atas ayah dan dua orang anak laki-lakinya. Sang ayah yang seorang wirausaha, tahun ini berumur 39 tahun. Tahun depan, selisih umur ayah dan anak tertuanya dibandingkan selisih umur ayah dan putra keduanya adalah $14: 19$.

Jika umur ayah sekarang adalah tiga kali umur anak tertuanya ditambah enam kali putra keduanya, maka jumlah umur anak pertama dan putra keduanya tiga tahun yang akan datang adalah?

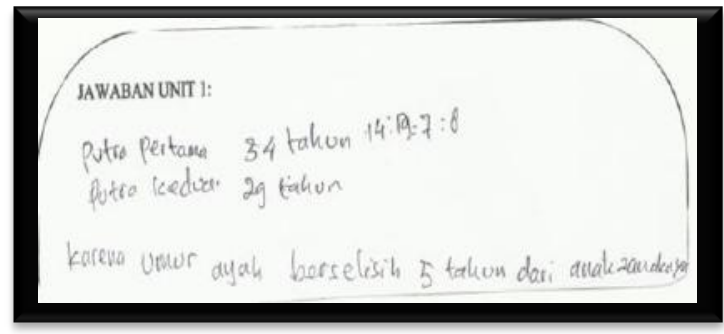

Gambar 1. Contoh kesalahan siswa. 


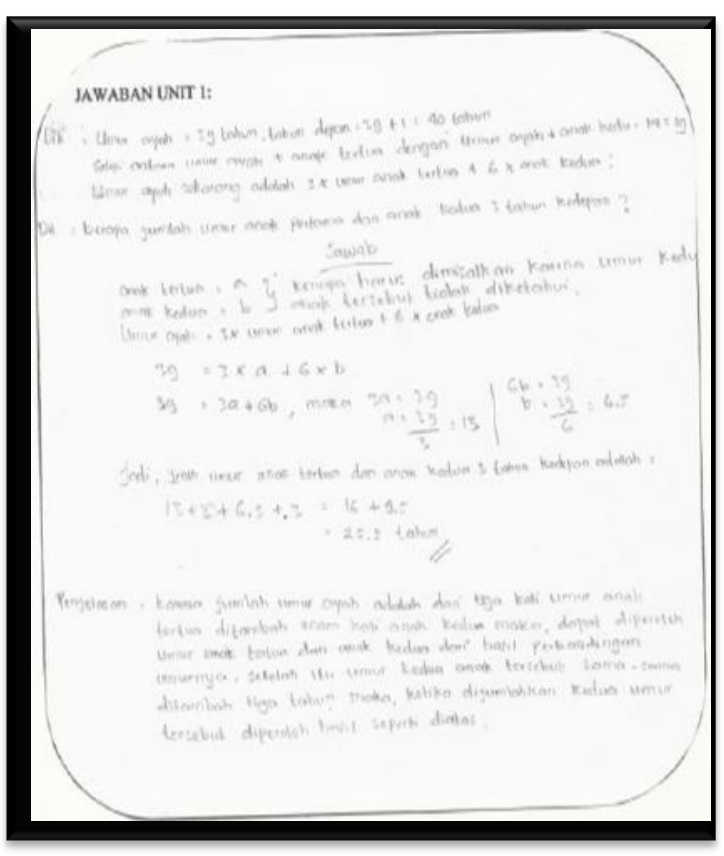

Gambar 2. Contoh jawaban siswa yang benar.

Berdasarkan analisis data hasil beajar yang didapat siswa setelah diterapkannya model pembelajaran Active Knowledge Sharing didapat nilai rata-rata siswa 75,4 nilai ini dikategorikan tuntas. Sedangkan

Berdasarkan analisis data observasi didapatkan rata-rata siswa per individu 13,0 ini dikategorikan tinggi. Dengan demikian model pembelajaran Active Knowledge Sharing dapat digunakan dalam pembelajaran matematika.

\section{Penutup}

Berdasarkan hasil penelitian yang telah dilakukan diperoleh rata-rata nilai aktivitas siswa setelah diterapkannya model pembelajaran Active Knowledge Sharing dikategorikan tinggi dengan nilai 13,0 dalam rentang 4-16 dan rata-rata hasil belajar siswa 75,4.

Adapun saran yang dapat peneliti berikan sebaai beikut:
1. Bagi guru diharapkan dapat menerapkan model pembelajaran Active Knowledge Sharing supaya dapat meningkatkan aktivitas siswa dalam selama proses pembelajaran berlangsung dan meningkatkan hasil belajar siswa.

2. Bagi peneliti diharapkan dapat menerapkan model pembelajaran Active Knowledge Sharing pada pokok bahasan yang lain.

\section{DAFTAR Pustaka}

[1] Benyamin Bloom, 1982

[2] Melvin Silberman, Active Learning. Bandung: Nusamedia, 2006.

[3] Soedjadi, 2000.

[4] Uzer Usman, Menjadi Guru Profesional, Bandung: PT. Remaja Rosdakarya, 2009.

[5] Suharsimi Arikunto, Dasar-dasar Evaluasi Pendidikan, Jakarta: Bumi Aksara, 2009.

\section{Riwayat Hidup Penulis}

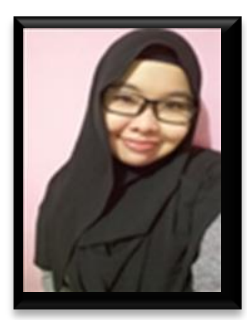

Eka Fitri Puspa Sari, M.Pd. Lahir di Palembang, 12 Mei 1986. Saat ini menjadi staf pengajar di Universitas PGRI Palembang pada program studi pendidikan Matematika. Peneliti menyelesaikan masa studi S.1 di Universitas Sriwijaya pada program studi pendidikan matematika tahun 2010, kemudian melanjutkan program pasca sarjana di unversitas sriwijaya pada program studi magister pendidikan matematika dan lulus tahun 2012. 

e-mosharafa.org

This page is intentionally left blank 